\title{
PELATIHAN PEMBUATAN PUPUK ORGANIK DARI LIMBAH SAYURAN DI DESA PESANGGRAHAN KOTA BATU
}

\author{
M. Istnaeny Hudha ${ }^{1}$, Rini Kartika Dewi, Faidliyah Nilna Minah, Jimmy \\ ${ }^{1}$ Prodi Teknik Kimia Institut Teknologi Nasional (ITN) Malang \\ E-mail address : istnaeny.hudha@lecturer.itn.ac.id
}

\begin{abstract}
Pesanggrahan village is located under Panderman mountain, Batu city. Most of its residents are farmers and ranchers and some are entrepreneurs. The most dominant numbers are farmers and cattle breeders. To accommodate the activities of farmers and breeders, the "Urip Sejahtera" Farmer Group was formed. Along with the development of increasingly advanced agriculture, the use of chemical fertilizers is increasing. This of course has a serious impact on soil conditions. So that an action is needed to find a solution to improve the nutrients in agricultural land.

Vegetable waste generated from agricultural activities is an unsolved problem. The waste produced by humans consists of organic and inorganic waste. Organic waste that is produced from vegetable waste is generally thrown away and can cause an unpleasant aroma, besides that it will also trigger the growth of disease-causing microorganisms. The goal to be achieved from the training activities for making organic fertilizer from vegetable waste is to provide information, knowledge and to raise public awareness of the importance of efficient waste management, so that the people of Pesanggrahan Village, Batu City do not carelessly dispose of vegetable waste. The method applied in this activity is to present the material then carry out direct practice to make organic fertilizer. Then do an evaluation of the resulting product.
\end{abstract}

Keywords: Vegetable Waste, Fermentation, Organic Fertilizer

\begin{abstract}
Abstrak
Desa Pesanggrahan terletak dibawah gunung Panderman kota Batu. Sebagian besar warganya merupakan petani dan peternak serta sebagian sebagai wiraswastawan. Jumlah yang paling dominan sebagai petani dan pertenak sapi. Untuk mewadahi kegiatan para petani dan peternak dibentuklah Kelompok Tani "Urip Sejahtera". Seiring berkembangnya pertanian yang semakin maju maka penggunaan pupuk kimia semakin meningkat. Hal ini tentu mempunyai dampak yang serius terhadap kondisi tanah. Sehingga diperlukan suatu tindakan mencari solusi untuk memperbaiki unsur hara di lahan pertanian.
\end{abstract}


Limbah sayuran yang dihasilkan dari aktivitas pertanian merupakan permasalahan yang belum terpecahkan. Limbah yang dihasilkan manusia terdiri dari limbah organik dan an-organik. Limbah organik yang dihasilkan bersumber dari limbah sayur umumnya dibuang begitu saja dapat menimbulkan aroma yang tidak sedap, selain itu juga akan memicu pertumbuhan mikroorganisme penyebab penyakit. Tujuan yang ingin dicapai dari kegiatan pelatihan pembuatan pupuk organik dari limbah sayuran adalah memberikan informasi, pengetahuan serta menumbuhkan kesadaran masyarakat terhadap pentingnya pengolahan limbah secara efisien, sehingga masyarakat Desa Pesanggrahan Kota Batu tidak sembarangan membuang limbah sayur. Metode yang diterapkan dalam kegiatan ini adalah menyajikan materi kemudian melakukan praktik langsung untuk membuat pupuk organik. Kemudian dilakukan evaluasi terhadap produk yang dihasilkan.

Kata Kunci: Limbah Sayur, Fermentasi, Pupuk Organik

\section{PENDAHULUAN}

Limbah organik dapat dihasilkan oleh aktivitas pertanian pasca panen dan kehidupan rumah tangga yang bersumber dari sampah dapur sisa kegiatan masak memasak. Limbah tersebut apabila jika dibuang begitu saja dapat menimbulkan aroma yang tidak sedap, selain itu juga akan memicu pertumbuhan mikroorganisme penyebab penyakit, degradasi kebersihan lingkungan karena mengeluarkan gas metan yang menyebabkan global warming (Indriyanti, Banowati, \& Margunani, 2015). Limbah sayuran pasca panen menjadi fokus utama yang akan diangkat dalam pengabdian masyarakat. Pada saat masa panen sayuran mencapai puncaknya, pemanfaatannya hanya dijadikan sebagai pakan ternak. Hal ini tentunya tidak mencukupi sehingga menimbulkan persoalan lingkungan. Kegiatan ini merupakan tindak lanjut dari hasil penelitian tentang pemanfaatan limbah sayuran sebagai bahan pembuatan miroorganisme lokal (MOL) yang berfungsi sebagai decomposer yang ramah lingkungan.

Salah satu cara yang dapat menyelesaikan persoalan limbah sayuran adalah dengan pendekatan teknologi yaitu merubahnya menjadi pupuk (Aklis \& Masyrukan, 2016). Berdasarkan urairan tersebut maka dilakukan pelatihan pembuatan Pupuk Organik dari limbah sayuran. Adapun produk yang akan dihasilkan dari pelatihan pembuatan pupuk ini adalah pupuk cair dan pupuk padat. Pupuk yang dihasilkan dapat dimanfaatkan sebagai pupuk alami yang sekaligus dapat memperbaiki unsur hara dalam tanah pertanian di desa 
Pesanggrahan akibat penggunaan pestisida dan pupuk kimia.

Dengan adanya kegiatan pelatihan ini diharapkan dapat menumbuhkan kesadaran masyarakat akan pentingnya hidup sehat dan kreatif sehingga dapat ditularkan kepada warga lain. Kreatif yang dimaksud adalah kreatif mengolah limbah menjadi bahan yang lebih bermanfaat dan bernilai ekonomis. Produksi Pupuk Organik dalam skala besar akan dapat mendatangkan nilai ekonomis. Selain itu, penggunaan Pupuk Organik ini diharapkan dapat memotivasi masyarakat untuk hidup sehat dengan tidak mendekati pestisida dan pupuk kimia, yang kemudian beralih kepada pupuk organik.

Permasalahan Mitra saat ini adalah 1. Mitra hanya memanfaatkan limbah sayuran pasca panen sebagai pakan ternak dan belum terpikirkan jika dapat diolah sebagai pupuk organik yang ramah lingkungan. 2. Mitra belum mempuyai alat \& teknologi tepat guna untuk membuat pupuk organik. Oleh karena itu diperlukan pendampingan yang dikemas dalam suatu pelatihan guna mengenalkan teknologi tepat guna pembuatan pupuk organik.

Dari permasalahan di atas, maka kami mencoba memanfaatkan limbah sayuran pasca panen sebagai sumber mikroorganisme lokal (mol) yang akan digunakan sebagai dekomposer pada saat pembuatan pupuk organik. Ada dua macam produk yang dihasilkan yaitu pupuk organik cair (POC) dan pupuk organik padat (kompos).

Pengabdian ini merupakan aplikasi dari hasil penelitian tentang proses pembuatan mikroorganisme lokal yang berbahan baku limbah sayuran. Adapun komposisi air cucian beras dan gula pasir yang tepat untuk hasil jumlah mikroba terbanyak yaitu $91 \times 10^{5} \mathrm{Koloni} / 100 \mathrm{~mL}$ dalam MOL limbah sayuran adalah 650 $\mathrm{mL}$ air cucian beras dan 100 gram gula pasir

Target Dan Luaran dari kegiatan ini adalah: 1. Target pelatihan ini adalah masyarakat yang tergabung dalam kelompok tani mampu membuat mikroorganisme alam (MOL) sebagai dekomposer alami dengan memanfaatkan limbah sayur dan buah-buahan sebagai bahan baku. MOL yang dihasilkan dijadikan sebagai dekomposer dalam pembuatan pupuk organik

2. Luaran dari pelatihan ini berupa produk dekokomposer (MOL), TTG fermentor sederhana, dan jurnal Pengabdian Kepada Masyarakat

\section{METODE DAN PELAKSANAAN}

Metode yang diterapkan dalam kegiatan ini adalah pelatihan dan praktik langsung. Dalam pelatihan ini diberikan 
beberapa kegiatan yang meliputi penyajian materi, dan praktik pembuatan Pupuk Organik. Adapun tahapan pelaksanaannya meliputi: 1. Persiapan. Pada tahap ini dilakukan koordinasi tim pelaksana terkait tempat pelaksanaan praktik dan penyajian materi. Selain itu melakukan koordinasi ke Ketua Kelompok Tani Sumber Urip Desa Pesanggrahan Kota Batu. Koordinasi dilakukan untuk memperoleh waktu dan data peserta dalam pelaksanaan pelatihan pembuatan pupuk organik. Selanjutnya menyiapkan limbah sayur dan bahan pendukung lainnya dalam pembuatan MOL. MOL merupakan merupakan kultur campuran dari mikroorganisme yang digunakan untuk meningkatkan populasi mikroorganisme, Penggunaan MOL bertujuan untuk mempercepat proses pembuatan pupuk organik, menetralkan bahan organik, dan meningkatkan kualitas pupuk. Pada kegiatan ini juga digunakan molase berupa gula putih sebagai tambahan sumber karbohidrat pada medium pertumbuhan mikroorganisme (Fifendy, Eldini, \& Irdawati, 2013). 2. Pelaksanaan pelatihan. Tahap ini merupakan tahap pelatihan pembuatan pupuk organik yang meliputi beberapa hal berikut:

a. Penyajian materi . Materi yang disajikan terkait pemanfaatan limbah sayuran sebagai bahan pembuatan MOL dan limbah sayuran menjadi pupuk organik seperti proses pembuatannya, bahan-bahan yang butuhkan dan mekanisme saat proses pembuatannya. Materi disajikan dalam bentuk presentasi. Selain itu, juga disampaikan beberapa manfaat pupuk organik serta kelebihannya dibanding pupuk kimia lainnya.

\section{b. Praktik pembuatan Pupuk}

Organik. Setelah mendapatkan teori, peserta akan diajak praktik langsung membuat pupuk organik dari limbah sayuran. Pada tahap tahal peserta dibei pengetahuan tentang cara pembuatan mikrorganisme lokal (MOL) sebagai salah satu dekomposer ramah lingkungan. Selanjutnya peserta diberi pengetahuan tentang tahapan dalam pembuatan pupuk organik dengan baik dan benar sehingga dapat diperoleh pupuk yang berkualitas. Apabila timbul permasalahan pada tahap pembuatan pupuk maka tim pelaksana akan memberi solusi dengan penjelasanpenjelasan yang relevan, sehingga tujuan akhir dari program dapat tercapai.

c. Penutupan. Di akhir kegiatan peserta dan Tim melakukan refleksi hasil pelatihan dan para peserta juga memberikan evaluasi akan pelatihan ini. Setelah semua kegiatan yang telah direncanakan terlaksana, ketua tim Pengabdian menutup program dan memberikan pesan kepada segenap 
peserta pelatihan untuk menerapkan apa yang telah didapatkan untuk memperkaya pembelajaran kreativitas dan hidup sehat tanpa pestisida dan pupuk kimia serta tidak ada lagi menimbun limbah sayuran yang dapat berdampak munculnya bibit penyakit.

\section{Pelaksanaan Kegiatan}

Pelaksanaan kegiatan pengabdian masyarakat dilaksanakan di desa Pesanggrahan Kota batu pada tanggal 1415 Nopember 2020 dengan jumlah peserta sekitar 35 orang dengan latar belakang sebagai petani dan peternak.

\section{HASIL DAN PEMBAHASAN}

Pelaksanaan abdimas diawali dengan melakukan kunjungan ke lokasi Kelompok Tani Sumber Urip Desa Pesanggrahan Kota Batu. Pada tahap ini dilakukan persiapan operasional dan koordinasi tim pelaksana terkait tempat pelaksanaan praktik dan penyajian materi. Koordinasi dilakukan untuk memperoleh waktu, data peserta dalam pelaksanaan pelatihan, tempat pelatihan serta bahan dan peralatan yang dibutuhkan pembuatan pupuk organik.

Untuk mengoptimalkan pelaksanaan pelatihan, maka digunakan fermentor sederhana yang dimodifikasi saat pelatihan. Para petani diberikan kesempatan melakukan praktek secara mandiri dengan dibimbing tim abdimas.
Setiap tahapan dijelaskan tujuan dan proses nya.

Adapun beberapa aktivitas pelatihan dapat dilihat dari dokumentasi berikut:

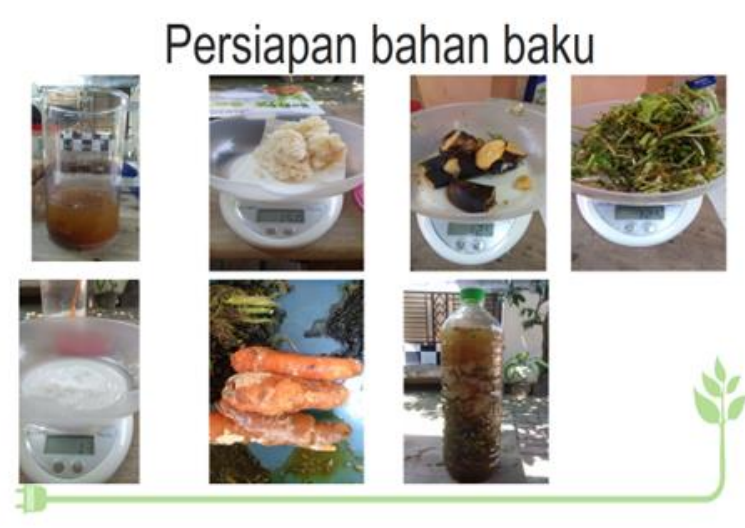

Gambar 1. Persiapan bahan
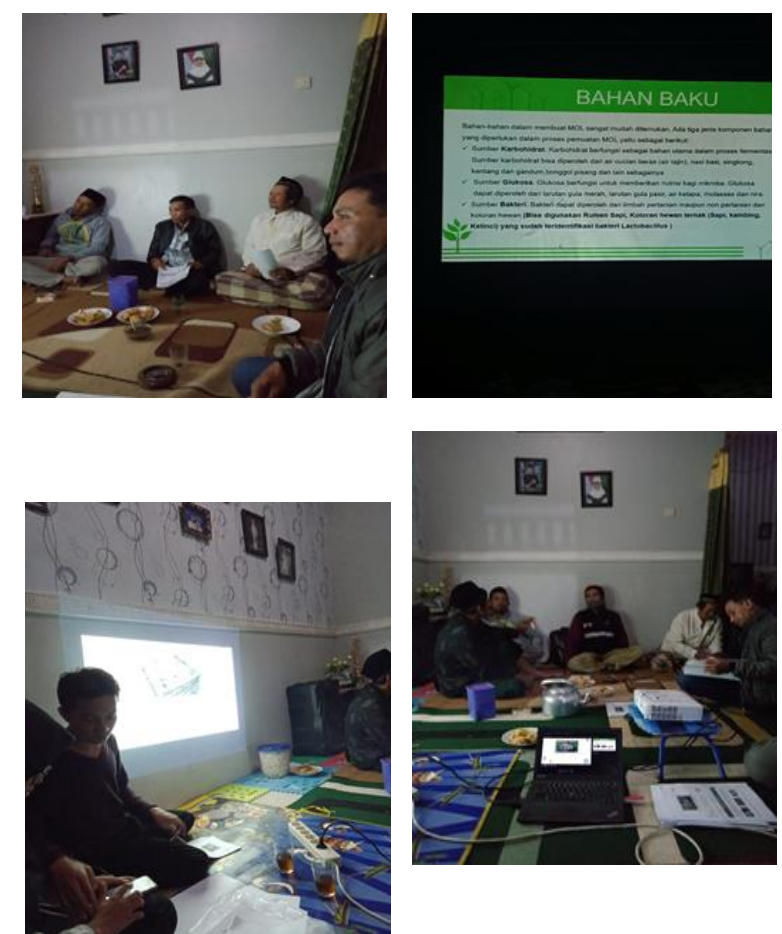

Gambar 2. Sosialisasi \& penyajian materi 

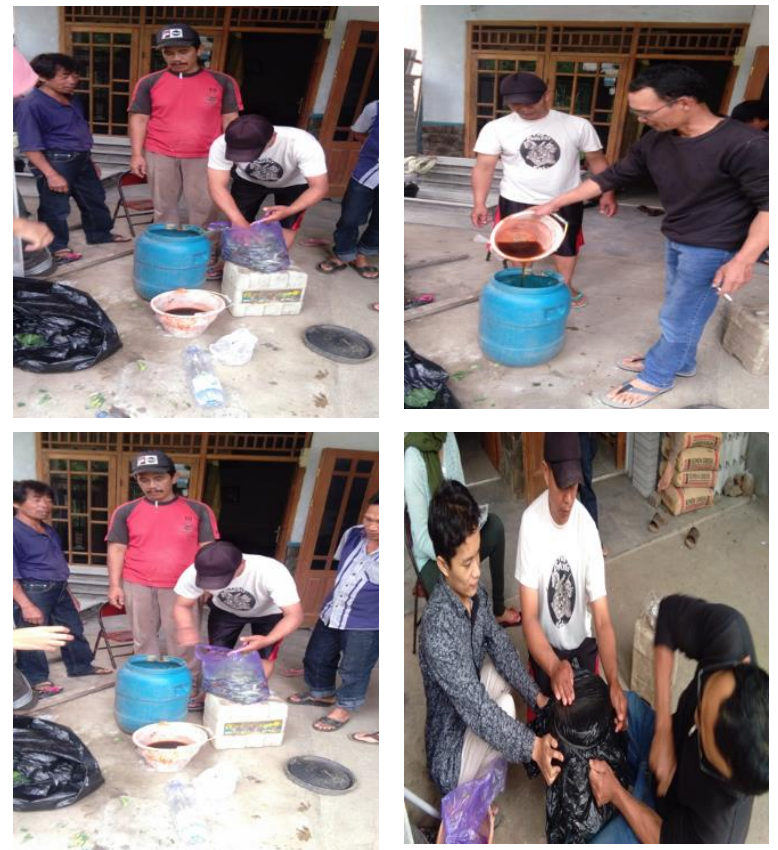

Gambar 3. Pelaksaan pelatihan pembuatan Pupuk Organik

\section{PENUTUP}

Pelatihan pembuatan pupuk organik dari limbah sayur dan buah-buahan merupakan terobosan pemanfaatan limbah yang selama ini pemfaatannya masih terbatas sebagai pakan ternak. Para petani berharap diberikan pelatihan sejenis dengan menfaatkan limbah organik disekitar mereka, mengingat bila musim panen limbah tersebut sangat melimpah dengan memanfaatkan teknologi tepat guna.

\section{Ucapan Terima Kasih}

Terima kasih kami sampaikan ke Lembaga Penelitian dan Pengabdian Masyarakat (LPPM) ITN Malang dan Kelompok Tani Urip Sehajtera Desa
Pesanggrahan Kota Batu ndari pernyataan terimakasih yang berlebihan.

\section{DAFTAR PUSTAKA}

Budiyani, Ni Komang; Soniari, Ni Nengah; Sutari, Ni Wayan Sri. 2016. Analisis Kualitas Larutan Mikroorganisme Lokal (MOL) Bonggol Pisang. E-Jurnal Agroekoteknologi Tropika, Volume 5 Nomor 1. ISSN 2301-6515.

Indriyanti Dyah Rini, Banowati Eva, Margunani. 2015. Pengolahan Limbah Organik Sanpah Pasar menjadi Kompos, Jurnal Abdimas Volume 19 No. 1.

Irpan; Caronge, Muh. Wiharto; Fadilah, Ratnawaty. 2018. Uji Kualitas MOL Air Buah Siwalan (Borassus flabellifer) Dengan Penambahan Berbagai Jenis Buah Berdasarkan Lama Fermentasi. Jurnal Pendidikan Teknologi Pertanian, Volume 4.

Khoiriyah, Ma'rifatul; Sutanto, Agus;

Sulistiani, Widya Sartika. 2017.

Pengaruh Macam Konsorsia Bakteri Indigen Terhadap Kualitas Pupuk Cair Urin Sapi. Prosiding Seminar Nasional Pendidikan. ISBN 978602-70313-2-6.

Manullang, Riama Rita; Rusmini dan Daryono. 2017. Kombinasi Mikroorganisme Lokal Sebagai 
Bioaktivator Kompos. Jurnal Hutan

Tropis Volume 5 No. 3.

Aklis Nur, Masyrukan, 2016, Penanganan

Sampah Organik dengan Bak

Sampah Komposter di Dusun

Susukan, Warta Volume 19 No. 1

MP, Lindung; Widyaiswara. 2015.

Teknologi Mikro Organisme EM4 dan Mol. BPP Jambi.

Palupi, Nurul Puspita. 2015. Karakteristik

Kimia Kompos Dengan Dekomposer

Mikroorganisme Lokal Asal Limbah

Sayuran. ZIRAA'AH, Volume 40

Nomor 1.

Sari, Dwi Riana; Santoso, Handoko; Zen,

Suharno. 2017. Pengaruh Macam

Konsorsia Bakteri Indigen LCN

Terhadap Kualitas Pupuk Cair

Limbah Tahu. Prosiding Seminar
Nasional Pendidikan. ISBN 978602-70313-2-6.

Suwatanti, EPS; Widiyaningrum, P. 2017. Pemanfaatan MOL Limbah Sayur Pada Proses Pembuatan Kompos. Jurnal MIPA 40 (1):1-6.

Syahrizal. 2015. Efektivitas Dosis EM4 (Effective Microorganism) Dalam Pembuatan Pupuk Cair Dari Sampah Organik. Jurnal Kesehatan Ilmiah Nasuwakes Vol.8 No.1.

Utama, CS; Mulyanto, A. 2009. Potensi Limbah Pasar Sayur Menjadi Starter Fermentasi. Jurnal Kesehatan.

W Amalia, Deasy; Widiyaningrum, Priyantini. 2016. Penggunaaan EM4 dan MOL Limbah Tomat Sebagai Bioaktivator Pada Pembuatan Kompos. 